\title{
Prevalence of Malaria Parasite among Asymptomatic and Symptomatic Students of Federal University of Technology, Akure, Ondo State
}

\section{Adepeju IS*}

Department of Biology, Federal University of Technology, P.M.B 704, Akure, Nigeria

*Corresponding author: Adepeju I, Department of Biology, Federal University of Technology, P.M.B 704, Akure, Nigeria, Tel: +234-08032296203; Email: adepejuolayemi@yahoo.com

Received Date: February 09, 2017; Accepted Date: March 10, 2017; Published Date: March 15, 2017

Copyright: (C) 2017 Adepeju IS. This is an open-access article distributed under the terms of the Creative Commons Attribution License, which permits unrestricted use, distribution, and reproduction in any medium, provided the original author and source are credited.

Citation: Adepeju IS. Prevalence of Malaria Parasite among Asymptomatic and Symptomatic Students of Federal University of Technology, Akure, Ondo State. Br J Res 2017, 4: 5.

\section{Abstract}

This study was carried out to determine the prevalence of malaria parasites infection among asymptomatic and symptomatic students of the Federal University of Technology, Akure, Nigeria. A total of 300 students (150 each for the two categories of students), 155(51.67\%) males and $145(48.33 \%)$ females; age range: $<20-30$ years were recruited for the study after informed consent. Both thick and thin films were made and stained using parasitological standard procedures after collection of blood samples from the students. Analysis of the result showed that $241(80.33 \%)$ of the subjects had malaria parasites, $80(53.3 \%)$ and $141(94.0 \%)$ prevalence for both categories respectively. Highest prevalence (59.0\%) and (94.4\%) was recorded among the males than the females $(46.3 \%)$ and (93.6\%) respectively for asymptomatic and symptomatic students. Age distribution showed the highest prevalence among subjects of age range $<20$ years in the two categories $(68.4 \%$ and $100 \%)$ while the least prevalence of $42.9 \%$, $76.9 \%$ and $48.3 \%$ were recorded among subjects of age range 25-27. According to Body index mass, the result showed that $55.0 \%$ of the infection occurred among underweight and $96.3 \%$ for normal weight for asymptomatic and symptomatic subjects with a significant difference $(p=0.01)$. On the use of Insecticide Treated Net for both categories of students, those using nets had the higher prevalence of malaria infection $61.9 \%$ and $94.4 \%$ respectively. Asymptomatic malaria was a risk factor among the students therefore measures to reduce the prevalence are advocated.

\section{Keywords:}

Asymptomatic; Symptomatic; Malaria parasite; Prevalence; Students

\section{Introduction}

Malaria is a mosquito-borne infection of human and animals caused by genus Plasmodium. Over 2 million febrile episodes and one million deaths are caused by malaria in sub-Saharan Africa [1]. Five species of Plasmodium can infect and transmit malaria to humans and majority of death are caused by $P$ falciparum, $P$ vivax, $P$ ovale, $P$ malaria and $P$ knowlesi [2]. Plasmodium infection remains an important cause of mortality and morbidity in many parts of the world and it could have adverse effect on the population, both on health and socioeconomic attitudes [3]

The WHO reports that, there are about 300-500 million incidences of malaria causing 2-3 million deaths each year in the tropical and subtropical regions of the world. About $90 \%$ of these deaths occur in Sub-Saharan Africa. This could be as a result of $P$. falciparum which is the most dangerous of the four parasites being the main cause of infections in this region and also the main malaria transmitting vector (Anopheles gambiae) being spread widely and very difficult to control [4]. Regardless of the soaring malaria incidence in endemic regions, a certain group of individuals seem to have more immunity to malaria than others. This could be accounted by several factors including haemoglobin vari- ants, $\mathrm{ABO}$ blood group system and enzyme action, among others [5].

Infection with Plasmodium falciparum has a wide spectrum of manifestations that are roughly classified into three clinical groups: asymptomatic infection, mild malaria and severe malaria. In malaria endemic areas, a large proportion of the populace harbour parasites without presenting signs of clinical malaria and are considered asymptomatic cases [6]. Asymptomatic carriers do not usually seek treatment for their infection and therefore constitute a reservoir of parasites available for transmission by Anopheles mosquitoes [7]. They were of the opinion that it may represent a mode of entry to symptomatic malaria, as well as transmission, especially in young children [8].

Despite recent progress leading to the reduction of malaria morbidity and mortality, there are both empirical and theoretical evidence that the current suite of interventions is insufficient to eliminate malaria from those areas in Sub-Saharan Africa with high levels of malaria transmission. In order to achieve reduced morbidity and mortality resulting from malaria, the infection must be recognized quickly so that patients are treated promptly. The clinical diagnosis of malaria is usually based on the patient's symptoms, which include fever, chills, sweats, headaches, muscle pains, nausea, and vomiting, which 
are also associated with other diseases. This makes early diagnosis difficult, leading to delays in the commencement of treatment [9].

The World Health Organization (WHO) recommends that the treatment of malaria should be based on a laboratory-confirmed diagnosis, with the exception of children less than 5 years of age in areas of high transmission in whom treatment may be provided on the basis of a clinical diagnosis. However, the high prevalence of asymptomatic infections and lack of resources such as microscopes and trained microscopists in highly endemic areas have led peripheral health facilities to use "presumptive treatment." Children who suffer from a fever that does not have any obvious cause are presumed to have malaria and are treated for that disease. Though this allows the rapid treatment of a potentially fatal disease, it can lead to incorrect diagnoses and unnecessary use of antimalarial drugs [10].

\section{Materials and Methods}

\section{Study Area}

The study was carried out at the Health centre of the Federal University of Technology, Akure. Akure, the capital city of Ondo State, South Western Nigeria. It is located on Longitude and Latitude with two distinct seasons, namely dry and wet seasons. The temperature ranges between $210 c-280 C$ and the vegetation is tropical rainforest.

\section{Study Population}

Three Hundred (300) students of the University who were the Health center attendees were recruited for this study between February to September, 2015.They consisted of 155 males and 145 females with their age ranging from 16 to 30 years. The weight and height of each participant was measured and used to determine the body mass index (BMI). The BMI was used to categorize each student into underweight $\left(<18 \mathrm{~kg} / \mathrm{m}^{2}\right)$, normal weight $\left(18-24.9 \mathrm{~kg} / \mathrm{m}^{2}\right)$ and overweight $\left(>25 \mathrm{~kg} / \mathrm{m}^{2}\right)[11]$.

\section{Ethical Clearance}

Approval for the study was given by the ethical committee of the University and the Chief Medical Director of the Health Centre. Informed consent of individual student was obtained and were asked orally if they were using insecticide treated net (ITN) with affirmative Yes or No before the collection of specimen.

\section{Specimen Collection and Processing}

5 millilitres of blood was collected from each student and dispensed into ethylene diamine tetra acetic acid (EDTA) bottle and mixed. Plasmodium infection was diagnosed through the examination of a Giemsa stained thick blood film. Thick blood films made from each of the blood sample and air dried. Slides were stained with $3 \%$ Giemsa stain for 30 minutes, rinsed with tap water and allowed to dry. Slides were examined for malaria parasites by microscope with an oil immersion objective lens.

\section{Data Analysis}

Data obtained were analysed using Chi square and Statistical significance was set at $p<0.05$.

\section{Results}

A total of $221(73.7 \%)$ were infected with malaria parasite out of the 300 students sampled. From the 150 Asymptomatic subjects sampled, 80 (53.3\%) were positive for malaria parasite while 141 (94.0\%) were positive for the Symptomatic students (Figure 1).

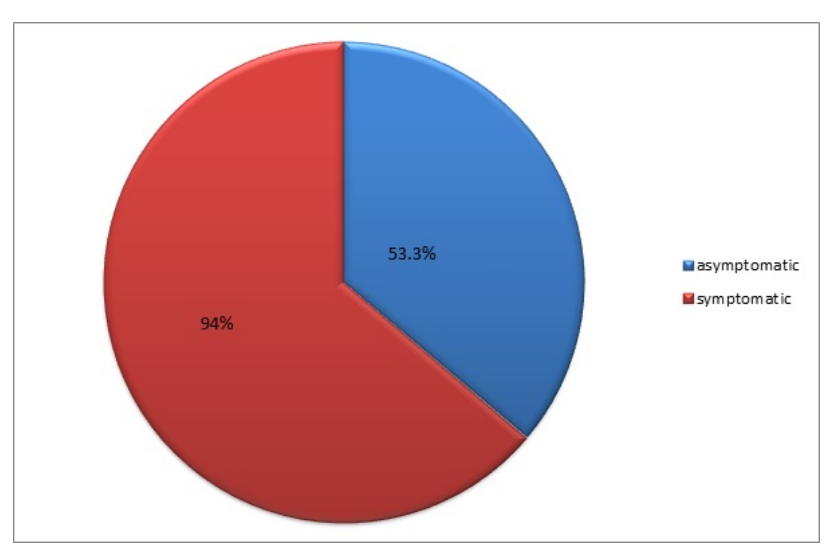

Figure 1: Percentage Distribution of asymptomatic and symptomatic malaria.

The prevalence of infection in relation to gender shows that for asymptomatic and symptomatic subjects males 49 (59.0\%) and $68(94.4 \%)$ were more infected than the females $31(46.3 \%)$ and $73(93.6 \%)$ respectively.

However there was no significant difference $\left(X^{2}=0.62\right)$ between the sex of the asymptomatic and symptomatic students (Table 1).

Table 1: Frequency and Distribution of asymptomatic and symptomatic malaria in relation to Gender.

\begin{tabular}{|c|c|c|c|c|c|c|}
\hline \multicolumn{3}{|c|}{ Asymptomatic } & \multicolumn{3}{|c|}{ Symptomatic } & \multirow[t]{2}{*}{$\begin{array}{l}x^{2}= \\
0.62\end{array}$} \\
\hline $\begin{array}{l}\text { Gend } \\
\text { er }\end{array}$ & $\begin{array}{l}\text { No } \\
\text { Teste } \\
\text { d }\end{array}$ & $\begin{array}{l}\text { No } \\
\text { Positive } \\
(\%)\end{array}$ & $\begin{array}{l}\text { Gend } \\
\text { er }\end{array}$ & $\begin{array}{l}\text { No } \\
\text { Teste } \\
\text { d }\end{array}$ & $\begin{array}{l}\text { No } \\
\text { Positive } \\
(\%)\end{array}$ & \\
\hline Male & 83 & $49(59.0)$ & Male & 72 & $68(94.4)$ & \\
\hline $\begin{array}{l}\text { Femal } \\
\mathrm{e}\end{array}$ & 67 & $31(46.3)$ & $\begin{array}{l}\text { Femal } \\
\mathrm{e}\end{array}$ & 78 & $73(93.6)$ & \\
\hline Total & 150 & 80 & & 150 & 141 & \\
\hline $\begin{array}{l}x^{2}= \\
0.39\end{array}$ & & & $\begin{array}{l}X^{2}= \\
0.97\end{array}$ & & & \\
\hline
\end{tabular}

Table 2 shows the prevalence of infection in relation to age, age group $<20$ recorded the highest positive cases $(68.4 \%)$ while the least was in age group 25-27 for asymptomatic students. Among the symptomatic students, almost all the age groups recorded high prevalence while age group 25-27 also recorded 
the least. Between the two groups, there was no significant difference in the age groups $\left(X^{2}=0.60\right)$.

Table 2: Frequency and Distribution of asymptomatic and symptomatic malaria in relation to Age.

\begin{tabular}{|c|c|c|c|c|c|c|}
\hline \multicolumn{3}{|c|}{ Asymptomatic } & \multicolumn{3}{|c|}{ Symptomatic } & $\begin{array}{l}X^{2}= \\
0.60\end{array}$ \\
\hline Age & $\begin{array}{l}\text { No } \\
\text { Teste } \\
\text { d }\end{array}$ & $\begin{array}{l}\text { No } \\
\text { Positive } \\
\text { (\%) }\end{array}$ & & $\begin{array}{l}\text { No } \\
\text { Teste } \\
\text { d }\end{array}$ & $\begin{array}{l}\text { No } \\
\text { Positive } \\
\text { (\%) }\end{array}$ & \\
\hline$<20$ & 38 & $26(68.4)$ & & 30 & $30(100)$ & \\
\hline $\begin{array}{l}20-2 \\
2\end{array}$ & 42 & $21(50.0)$ & & 44 & $42(95.4)$ & \\
\hline $\begin{array}{l}23-2 \\
5\end{array}$ & 29 & $13(44.8)$ & & 31 & $30(96.8)$ & \\
\hline $\begin{array}{l}25-2 \\
7\end{array}$ & 28 & $12(42.9)$ & & 26 & $20(76.9)$ & \\
\hline $\begin{array}{l}27-2 \\
9\end{array}$ & 10 & $6(60.0)$ & & 13 & $13(100)$ & \\
\hline$>29$ & 3 & $3(100)$ & & 6 & $6(100)$ & \\
\hline Total & 150 & 80 & & 150 & & \\
\hline $\begin{array}{l}X^{2}= \\
0.80\end{array}$ & & & $\begin{array}{l}X^{2}= \\
0.99\end{array}$ & & & \\
\hline
\end{tabular}

Table 3 shows that the prevalence of asymptomatic malaria among students who were overweight (40\%) was lower than those for normal weight (53.7\%) and underweight $(55.5 \%)$ and there was no significant difference $\left(X^{2}=0.87\right)$. For symptomatic malaria subjects, normal weight students (96.3\%) were more than the overweight (75.0\%). Also, there was no significant difference $\left(X^{2}=0.94\right)$. However, there was a significant difference between the body mass index of asymptomatic and symptomatic students $\left(X^{2}=0.01\right)$.

Table 3: The Effects of Body mass index on Asymptomatic and Symptomatic Malaria.

\begin{tabular}{|c|c|c|c|c|c|c|}
\hline \multicolumn{3}{|c|}{ Asymptomatic } & \multicolumn{3}{|c|}{ Symptomatic } & $\begin{array}{l}X^{2}= \\
0.01\end{array}$ \\
\hline Weight & $\begin{array}{l}\text { No. } \\
\text { Test } \\
\text { ed }\end{array}$ & $\begin{array}{l}\text { No. } \\
\text { Positive } \\
\text { (\%) }\end{array}$ & Weight & $\begin{array}{l}\text { No. } \\
\text { Test } \\
\text { ed }\end{array}$ & $\begin{array}{l}\text { No. } \\
\text { Positive } \\
\text { (\%) }\end{array}$ & \\
\hline $\begin{array}{l}\text { Under } \\
\text { weight }\end{array}$ & 60 & $33(55.0)$ & $\begin{array}{l}\text { Under } \\
\text { weight }\end{array}$ & 66 & $61(43.3)$ & \\
\hline $\begin{array}{l}\text { Normal } \\
\text { weight }\end{array}$ & 80 & $43(53.8)$ & $\begin{array}{l}\text { Normal } \\
\text { weight }\end{array}$ & 80 & $77(96.3)$ & \\
\hline $\begin{array}{l}\text { Over } \\
\text { weight }\end{array}$ & 10 & $4(40.0)$ & $\begin{array}{l}\text { Over } \\
\text { weight }\end{array}$ & 4 & $3(75.0)$ & \\
\hline Total & 150 & 80 & & 150 & 141 & \\
\hline $\begin{array}{l}\mathrm{X}^{2}= \\
0.87\end{array}$ & & & $\begin{array}{l}\mathrm{X}^{2} \\
0.94\end{array}=$ & & & \\
\hline
\end{tabular}

Out of the 150 asymptomatic students, $42.0 \%$ were using insecticide treated net (ITN) while 58.0\% were not using, but the former were more positive (61.9\%) against the latter $(47.1 \%)$ to malaria. From 150 symptomatic subjects, $47.3 \%$ said yes to ITN while $52.7 \%$ said no. The students using ITN recorded higher prevalence $(94.4 \%)$ against $(93.7 \%)$ of those not using ITN. There was no significant difference $\left(X^{2}=0.86\right)$ (Table 4$)$.

Table 4: Relationship between usage of Insecticide Treated Net and Asymptomatic and Symptomatic Malaria.

\begin{tabular}{|c|c|c|c|c|c|c|}
\hline \multicolumn{3}{|c|}{ Asymptomatic } & \multicolumn{3}{|c|}{ Symptomatic } & \multirow[t]{2}{*}{$\begin{array}{l}x^{2}= \\
0.86\end{array}$} \\
\hline & $\begin{array}{l}\text { No } \\
\text { Test } \\
\text { ed }\end{array}$ & $\begin{array}{l}\text { No } \\
\text { Positive } \\
\text { (\%) }\end{array}$ & $\begin{array}{l}\text { Respo } \\
\text { nse }\end{array}$ & $\begin{array}{l}\text { No } \\
\text { Test } \\
\text { ed }\end{array}$ & $\begin{array}{l}\text { No } \\
\text { Positive } \\
(\%)\end{array}$ & \\
\hline \multicolumn{6}{|l|}{$\begin{array}{l}\text { Respon } \\
\text { se }\end{array}$} & \\
\hline Yes & 63 & $39(61.9)$ & Yes & 71 & $67(94.4)$ & \\
\hline No & 87 & $41(47.1)$ & No & 79 & $74(93.7)$ & \\
\hline Total & 150 & 80 & & 150 & 141 & \\
\hline $\begin{array}{l}\mathrm{X}^{2} \\
0.32\end{array}$ & & & $\begin{array}{l}\mathrm{x}^{2} \\
0.96\end{array}=$ & & & \\
\hline
\end{tabular}

\section{Discussion}

The distribution and efficiency of the insect vectors, climatic and environmental factors, acquired immunity and the behavior of the human population are some of the variables in malaria infection [12]. A prevalence of $80.3 \%$ of both asymptomatic and symptomatic malaria among the students was observed in the study. In a similar study conducted among first year students of Nnamdi Azikiwe University, Awka, Southeastern Nigeria, a prevalence of $80.0 \%$ was reported [13]. These findings further confirm the endemicity of this infection even among the students, population. Despite the advances in the understanding of the pathogenic and clinical aspects of malaria, it is not well known why some people tolerate malaria infection with few or no symptoms whereas others are severely affected [14]. In this study, $53.3 \%$ of the150 students of the Federal University of Technology, Akure who were tested had malaria parasites yet they are asymptomatic. The prevalence recorded in asymptomatic subjects is higher than the previous results of $50.5 \%$ and $33.5 \%$ in Ipogun, Ondo State and Benin City respectively $[12,15]$. Bites of the same mosquito species or the same strain of plasmodium can create more chance of infection.

The result also shows a higher prevalence (59.0\%) and (94.4\%) among the male students than the female students with prevalence of $42.9 \%$ and $93.6 \%$ respectively in both asymptomatic and symptomatic students, although there was no significant difference ( $p>0.05)$. The higher prevalence $(59.0 \%)$ observed for the asymptomatic males in this study is in disagreement with findings of $[13,16]$ but in agreement with the findings of [17-19] who found higher prevalence among the males than the females. However, there appears to be no scientific evidence linking malaria prevalence to gender [20].

The highest prevalence of malaria for the two categories was in age group $<20$ years while the least prevalence was among age group 25-27 years. This result agrees with the finding of [21] that parasite density falls as age increases suggesting agedependent immunity to Plasmodium among adults. 
In this study, Body Index Mass (BIM) did not significantly $(\mathrm{P}=0.87)$ affect the prevalence of asymptomatic and symptomatic $(P=0.94)$. However, there is a significant difference $(P=0.01)$ between BIM in the two categories of students. Excess weight contributes to several health related complications which may include diabetes, cancers, kidney disease and hypertension [11]. It is indicated that obesity resulted in decreased immune counts and functions [22].

The use of Insecticide Treated Nets (ITNs) did not affect the prevalence of both types of malaria. For asymptomatic students using ITNs, 39 (61.9\%) were positive for malaria parasites while for symptomatic students, 67 (94.4\%) were also positive. There was no significant difference $(p>0.05)$. Low, infrequent and improper use of ITNs in a malaria endemic community may have contributed to its less efficacy in this study as previously reported by $[23,24]$. Detection of the parasite in asymptomatic subjects could be as a result of acquired immunity in the subjects due to repeated exposure to mosquito bites. The subjects included in this study are students who must have come from different environments ranging from urban to rural areas and different background and status.

\section{Conclusion}

The results of this study suggest that fever is not always indicative of the presence of malaria parasite and that subjects with asymptomatic infection must be regarded as a significant reservoir of transmissible malaria parasites within the study environment. It is important to note that for malaria control measures to be effective, both asymptomatic and symptomatic individuals must be included in the management strategies.

\section{Acknowledgement}

The author appreciates the Chief Medical Director and the Technologists of the Federal University of Technology Health Centre, Akure and also the students for their cooperation and participation in this study.

\section{References}

1. World Health Organization (2013) Malaria Vector species complexes and Intraspecific Variation: Relevance for malaria control. TDR/Fieldmal-SWG.

2. Coluzzi M (2013) Malaria and the Afrotropical Ecosystem, Impact of Man-made Environmental changes. Parasitogia 11: 191-200.

3. Zoghi S, Mehrizi AA, Raeisi A, Haghdoost AA, Turki $H$, et al. (2012) Survey of asymptomatic malaria cases in low transmission settings of Iran under elimination programme. Malaria Journal, 11: 126-136, 2012.

4. World Health Organization (2003) The African Malaria Report. Whoint/features.

5. Otajevwo FD (2013) Prevalence of Malaria Parasitaemia and Its Association with $\mathrm{ABO}$ Blood Grouping among Students of
Igbinedion University Okada, Nigeria. British Journal of Medicine \& Medical Research 3: 1164-1177.

6. Mombo LE, Ntoumi F, Bisseye C, Ossari S, Lu CY, et al. (2003) Human genetic polymorphisms and asymptomatic Plasmodium falciparum malaria in Gabonese school children. American Journal of Tropical Medicine and Hygiene 68: 186-190.

7. Kimbi HK, Keka FC, Nyabeyeu HN, Ajeagah HU, Tonga CF (2012) An Update of Asymptomatic Falciparum Malaria in School Children in Muca, Southwest Cameroon. Journal of Bacteriology and Parasitology 3: 154.

8. Henning L, Schellenberg $D$, Smith $T$, Henning $D$, Alonso $P$ (2004) A prospective study of Plasmodium falciparum multiplicity of infection and morbidity in Tanzanian children. Transaction of the Royal Society of Tropical Medicine and Hygiene 98: 687-694.

9. Lindblade KA, Steinhard T, Samnels A, Kachur SP, Slutsker L (2013) The silent Threat: Asymptomatic parasiteamia and malaria transmission. Expert Re. Infect Ther 11: 623-39.

10. Brejman JG (2001) The ears of Hippopotamus: Manifestations, determinants and estimates of malaria burden. Am J Trop Med Hyg 64: 1-11.

11. Crum-Cianflone NF, Roediger M, Eberly LE, Ganesan A, Weintrob A, et al. (2011) Impact of weight on immune cell count among HIV-infected persons. Clinical and Vaccine Immunology 18: $940-946$.

12. Akinbo FO, Adetitun AJ, Aruomaren Al, Okaka CE (2013) Asymptomatic Malaria Infection and Anaemia among Secondary School Children in Ipogun, Ondo State, Nigeria. Nig J Life Sc 3: 24-29.

13. Ibekwe AC, Okonko IO, Onunkwo Al, Ogun AA, Udeze AO (2009) Comparative Prevalence Level of Plasmodium in freshmen (First Year Students) of Nnamdi Azikiwe University in Awka, South-Eastern, Nigeria. Malaysian Journal of Microbiology 5: 51-54.

14. Azeez OM, Raji Y (2007) Family experience of ill health characteristics during rainy seasons. Sci Focus 12: 130-136.

15. Osazuwa F, Oguntade MA (2010) Contribution of malnutrition and malaria to anaemia children in rural communities of Edo State, Nigeria. North American Journal of Medical Sciences 2: 532-536.

16. Okonko IO, Soleye FA, Amusan TA (2009) Prevalence of malaria plasmodium in Abeokuta, Nigeria. Malaysian Journal of Microbiology 5: 133-118, 2009.

17. Eke RA, Chigbu LN, Nwachukwu W (2006) High Prevalence of Asymptomatic Plasmodium Infection in a suburb of Aba Town, Nigeria. Annals of African Medicine 5: 42-46.

18. Epidi TT, Nwani CD, Ugorji NP (2008) Prevalence of Malaria in Blood Donors in Abakaliki Metropolis, Nigeria. Scientific Research and Essay 3: 162-164.

19. llozumba PCO, Uzozie CR (2009) Prevalence of Malaria Parasitaemia and its Association with $A B O$ Blood Group in Odoakpu Area of Onitsha South Local Government Area, 
Anambra State, Nigeria. Nigerian Annals of Natural Sciences 8: 1-8.

20. Udeze AO, Nwokocha EJ, Okerentugba PO, Anibijuwon II, Okonko IO (2013) Asymptomatic Plasmodium parasitaemia in Ilorin, North Central, Nigeria. Nat Sci 11: 24-28.

21. Munyekenye OG Githeko AK, Zhou G, Mushinzimana E, Minakawa N, et al. (2005) Plasmodium falciparum spatial analysis, western Kenya highlands. Emerging Infectious Diseases 11: 1571-1577.

22. Tanaka SI, Isoda F, Ishihara Y, Kimura M, Yamakawa TT (2001) lymphopaenia in relation to body mass index and TNF in human obesity: adequate weight reduction can be corrective. Clinical Endocrinology 54: 347-354.

23. Oladeinde $\mathrm{BH}$, Omoregie $\mathrm{R}$, Olley $\mathrm{M}$, Anunibe JA, Onifade AA et al. (2012) Malaria and Anaemia amongchildren in low resource setting in Nigeria. Iranian Journal of Parasitology 7: 31-37.

24. World Health Organization (2010) Malaria. WHO Fact Sheet No. 94, WHO Media centre, Geneva. 